Note

\section{Purification and Characterization of Lectin from Auricularia polytricha}

\author{
Fumio YaGI and Kenjiro TADERA
}

\author{
Laboratory of Biochemistry and Nutritional Chemistry, \\ Department of Agricultural Chemistry, \\ Kagoshima University, \\ Korimoto 1-21-24, Kagoshima 890, Japan
}

Received November 26, 1987

Several novel lectins have been purified to homogeneous states from fungi including edible mushroom. ${ }^{\sim \sim 5}$ Aragekikurage (Auricularia polytricha) is a kind of edible mushroom which belongs to Heterobasidiae of Basidiomycetes, and no lectin has been purified from this subclass of Basidiomycetes.

In this paper, we describe the purification and characterization of a lectin from this mushroom.

Ovomucoid $(400 \mathrm{mg}$ ) was dissolved in $10 \mathrm{ml}$ of $1 \mathrm{~m}$ potassium phosphate buffer, $\mathrm{pH} 6.8$, containing $0.1 \%$ sodium azide. Five grams of Eupergit $\mathrm{C}$ was incubated with the ovomucoid solution at $25^{\circ} \mathrm{C}$. After $72 \mathrm{hr}$ of incubation, Eupergit $\mathrm{C}$ was collected with a glass filter, and washed with $0.1 \mathrm{M}$ sodium phosphate buffer, $\mathrm{pH}$ 7.0. On the basis of absorption at $280 \mathrm{~nm}, 60 \%$ of ovomucoid was calculated to be coupled to Eupergit C.

Lectin activity was measured as hemagglutinating activity by a serial 2 -fold dilution method, using a $4 \%$ suspension of trypsinized human type B erythrocytes in $0.9 \% \mathrm{NaCl}$ solution, as previously described ${ }^{6}{ }^{6}$ Protein was measured by a modification of Lowry's method ${ }^{7}$ with bovine serum albumin as a standard.

The purification procedures are as follows. Five hundred grams of raw mushroom was homogenized with 1.21 of $50 \mathrm{~mm}$ sodium phosphate buffer, $\mathrm{pH} 7.0$, containing $2 \% \mathrm{NaCl}, 1 \mathrm{~mm}$ phenylmethanesulfonate fluoride (PMSF), and $1 \mathrm{~mm}$ EDTA. The homogenate was stirred for $3 \mathrm{hr}$ at $0^{\circ} \mathrm{C}$. Then $50 \mathrm{~g}$ of polyvinylpyrrolidone was added to the homogenate, and the suspension was stirred for another $1 \mathrm{hr}$. After centrifugation, a clear supernatant solution was obtained, and the solution was passed through a Celite column $(3 \times 20 \mathrm{~cm})$. The column was washed with $200 \mathrm{ml}$ of $50 \mathrm{~mm}$ sodium phosphate buffer, $\mathrm{pH} 7.0$, containing $2 \%$ $\mathrm{NaCl}$. The effluent and washings were combined, and solid ammonium sulfate was added to the combined solution $(80 \%$ saturation). The precipitated protein was collected by centrifugation, and suspended in $100 \mathrm{ml}$ of $20 \mathrm{~mm}$ sodium phosphate buffer, $\mathrm{pH} 7.0$, containing $1 \mathrm{mM}$ PMSF and I mM EDTA. The suspension was dialyzed against
$20 \mathrm{~mm}$ sodium phosphate buffer, $\mathrm{pH} 7.0$. The dialysate was centrifuged, and the supernatant solution was put on a column of DEAE-Toyopearl $650 \mathrm{M}(3.5 \times 11 \mathrm{~cm})$, previously equilibrated with the same buffer. By washing with $20 \mathrm{~mm}$ sodium phosphate buffer, $\mathrm{pH} 7.0$, most of lectin activity was eluted. Then adsorbed protein was eluted with $20 \mathrm{~mm}$ sodium phosphate buffer, containing $1 \mathrm{M} \mathrm{NaCl}$. Only several percent of the activity was adsorbed on the column. The protein in the through fraction was precipitated with ammonium sulfate $(90 \%$ saturation). The lectin was further purified by affinity chromatography on ovomucoid-Eupergit $\mathrm{C}$. The protein precipitate was collected by centrifugation, and suspended in $0.1 \mathrm{M}$ sodium phosphate buffer, $\mathrm{pH}$ 7.0. The suspension was stirred for $1 \mathrm{hr}$ at $0^{\circ} \mathrm{C}$, and then centrifuged at $35,000 \times g$ for $30 \mathrm{~min}$. After centrifugation, the precipitate was removed, and the supernatant was put on the affinity column $(2.5 \times 6 \mathrm{~cm})$, previously equilibrated with $0.2 \mathrm{M}$ sodium phosphate buffer, $\mathrm{pH}$ 7.0. The column was washed with $0.2 \mathrm{M}$ sodium phosphate buffer, $\mathrm{pH} 7.0$, and then $1 \mathrm{~m}$ ammonium hydroxide and $0.2 \mathrm{M}$ glycine- $\mathrm{HCl}$ buffer, $\mathrm{pH} 2.2$, containing $0.5 \mathrm{M} \mathrm{NaCl}$ were used for the elution of lectin. Most of the lectin activity was eluted by the glycine- $\mathrm{HCl}$ buffer, and the eluted lectin fraction was rapidly neutralized with conc, ammonium hydroxide. The lectin was precipitated with ammonium sulfate $(90 \%$ saturation). Finally the lectin was purified by gel filtration on Toyopearl HW 55F. The protein collected by centrifugation was dissolved in

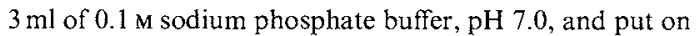
a column of Toyopearl HW 55F $(2.5 \times 140 \mathrm{~cm})$, equilibrated with the same buffer. Active fractions were combined and the lectin was concentrated by ammonium sulfate $(90 \%$ saturation).

By this purification, $1.6 \mathrm{mg}$ of lectin with a specific activity of 3,750 titer $/ \mathrm{mg}$ was obtained. Its purification was 290 -fold over the initial extract, and its recovery was $32 \%$. In the purification of lectin from $A$. polytricha, the affinity chromatography with ovomucoid-Eupergit $\mathrm{C}$ was effective to remove polysaccharide and for the increase of specific activity. The homogeneity of the purified lectin was confirmed by polyacrylamide gel electrophoresis at $\mathrm{pH} 4.3,{ }^{8)}$ and the protein band by Coomassie brilliant blue $\mathrm{R}-250^{9}$ ) coincided with the carbohydrate band by periodate-Schiff reagent ${ }^{10)}$ on the gel.

The molecular weight of the lectin was estimated to be 23,000 by HPLC with a Fine Pak SIL AF-102 column, ${ }^{11}$ sodium dodecyl sulfate polyacrylamide gel electrophoresis, ${ }^{12)}$ and gel filtration on Toyopearl HW 55F. Therefore, the lectin was assumed to be a monomeric protein. Further, this lectin could not be electrophoresed on a polyacrylamide gel at $\mathrm{pH} 8.3$, indicating that it was a basic protein. By gel isoelectric focusing, ${ }^{13)}$ it migrated to a position close to that of native cytochrome $c$.

The amino acid composition and carbohydrate content of the lectin from A. polytricha are shown in Table I. Sulfur-containing amino acids and histidine were not found in the lectin from A. polytricha. This might be a 
Table I. Chemical Composition of Lectin FROM A. polytricha

mol residue/mol protein ${ }^{a}$

\begin{tabular}{cc}
\hline Asx & 22 \\
Thr & $20^{b}$ \\
Ser & $10^{b}$ \\
Glx & 15 \\
Pro & 19 \\
Gly & 20 \\
Ala & 23 \\
l/2 Cys & $0^{c}$ \\
Val & 19 \\
Met & 0 \\
Ile & 10 \\
Leu & 10 \\
Tyr & 5 \\
Phe & 11 \\
Lys & 2 \\
His & 0 \\
Arg & 12 \\
Trp & $5^{d}$ \\
Glucosamine & $2^{e}$ \\
Neutral sugar & $3.5^{\circ}$ \\
\hline
\end{tabular}

" Average values of 24-, 48-, and 72-hydrolysates.

$b$ Values extrapolated to zero hydrolysis time.

c Value by the method of performic acid oxidation. ${ }^{14\}}$

d By the method of Edelhoch. ${ }^{15}$ )

e 10-hr hydrolysis with $2 \mathrm{~N} \mathrm{HCl}$.

$f$ By the phenol-sulfuric acid method of Dubois et al. ${ }^{16\}}$

common feature of the amino acid composition of mushroom lectins. The proline content was higher but the lysine content was very low. Though acidic amino acid content was very high, it was a basic protein. At least $80 \%$ of glutamic acid and aspartic acid were assumed to be in the amide form. A typical example of high amide content in basic proteins was reported for bovine trypsin. ${ }^{17}$ )

The hemagglutinating activity of the lectin from $A$. polytricha was tested with human and rabbit erythrocytes. Trypsinized human type A, B, and O erythrocytes, and trypsinized rabbit erythrocytes were equally agglutinated by the lectin, but all native erythrocytes were scarcely agglutinated.

Table II shows the inhibition of hemagglutinating activity of the lectin by various sugars. The hemagglutination of trypsinized human type $B$ erythrocytes was specifically inhibited by galactose and its derivatives. Betaanomers of galactoside inhibited the hemagglutination more strongly than $\alpha$-anomers. Other sugars including Dgalactosamine and $N$-acetyl-D-galactosamine did not show any effect up to $100 \mathrm{~mm}$. In this respect, this lectin resembles some galactose-binding lectins of plant origin from Ricinus communis, ${ }^{18 \sim 22)}$ Abrus precatorius, ${ }^{22)}$ and Momordica charantia. ${ }^{23,}$
TABLE II. Inhibition OF Hemagglutinating ACTIVITY OF $A$. polytricha LECTIN BY VARIOUS CARBOHYDRATES

Minimum sugar concentrations required for the complete inhibition of titer 4 hemagglutinating activity. The following sugars were not inhibitory at $100 \mathrm{mM}$; Dglucose, D-mannose, L-fucose, D-galactosamine, $N$ acetyl-D-galactosamine, and $N$-acetyl-D-glucosamine.

\begin{tabular}{lc}
\hline Sugar & $\begin{array}{c}\text { Concentration } \\
(\mathrm{mM})\end{array}$ \\
\hline D-Galactose & 3.12 \\
Lactose & 0.78 \\
$p$-Nitrophenyl- $\beta$-D-galactoside & 0.78 \\
$p$-Nitrophenyl- $\alpha$-D-galactoside & 12.5 \\
Raffinose & 6.25 \\
Ovomucoid & $1.56(\mathrm{mg} / \mathrm{ml})$ \\
\hline
\end{tabular}

Acknowledgement. The authors wish to thank Nan-Ei Togyo Co. (Kagoshima, Japan) for generous supply of raw Aragekikurage (A. polytricha).

\section{REFERENCES}

1) M. Tsuda, J. Biochem., 86, 1463 (1979).

2) N. Kochibe and K. Furukawa, Biochemistry, 19, 2841 (1980).

3) J. Guillot, L. Genaud, J. Gueugnot and M. Damez, Biochemistry, 22, 5365 (1983).

4) J. Y. Lin and T. B. Chou, J. Biochem., 96, 35 (1984).

5) S. Sueyoshi, T. Tsuji and T. Osawa, Biol. HoppeSeyler, 366, 213 (1985).

6) F. Yagi, M. Sakamoto, T. Sayawaki, K. Tadera, A. Kobayashi and K. Ishihata, Agric. Biol. Chem., 49, 3575 (1985).

7) E. F. Hartree, Anal. Biochem., 48, 422 (1972).

8) B. J. Davis, Ann. N.Y. Acad. Sci., 121, 404 (1964).

9) T. S. Meyer and B. L. Lamberts, Biochim. Biophys. Acta, 107, 144 (1965).

10) R. M. Zaccharius, T. E. Zell, J. H. Morrison and J. J. Woodlock, Anal. Biochem., 30, 148 (1969).

11) F. Yagi, J. Fan, K. Tadera and A. Kobayashi, Agric. Biol. Chem., 50, 1029 (1986).

12) K. Weber and M. Osborn, J. Biol. Chem., 244, 4406 (1969).

13) C. W. Wrigley, "Methods in Enzymology," Vol. 22, ed. by W. B. Jakoby, Academic Press Inc., New York, 1971, pp. 559 564.

14) C. H. W. Hirs, "Methods in Enzymology," Vol. 11, ed. by C. H. W. Hirs, Academic Press Inc., New York, 1967, pp. 59 62.

15) H. Edelhoch, Biochemistry, 6, 1948 (1967).

16) M. Dubois, K. A. Gilles, H. K. Hamilton, R. A. Rebers and F. Smith, Anal. Chem., 28, 350 (1956).

17) M. O. Dayhoff, "Atlas of Protein Sequence and 
Structure," Vol. 5, National Biomedical Foundation, Washington D. C., 1972.

18) G. L. Nicolson and J. Blaustein, Biochim. Biophys. Acta, 266, 543 (1972).

19) J. P. Van Wauwe, F. G. Loontiens and C. K. De Bruyne, Biochim. Biophys. Acta, 313, 99 (1973).

20) G. L. Nicolson, J. Blaustein and M. E. Etzler,
Biochemistry, 13, 196 (1974).

21) T. Irimura, T. Kawaguchi, T. Terao and T. Osawa, Carbohydr. Res., 39, 317 (1975).

22) S. Olsnes, E. Saltvedt and A. Pihl, J. Biol. Chem., 249, 803 (1974).

23) T. Mazumder, N. Gaur and A. Surolia, Eur. J. Biochem., 113, 463 (1981). 